\title{
The Application of the Farm Accounting Based on Sufficiency Economy Philosophy (SEP) in Order to Achieve Sustainable Development
}

\author{
Titi Rapini ${ }^{1}$, Rizki Listyono Putro ${ }^{2}$ \\ \{rizkylistyono@gmail.com² ${ }^{2}$ \\ Faculty of Economics, Universitas Muhammadiyah Ponorogo, Indonesia 1,2
}

\begin{abstract}
The study of social and environmental accounting reveals a lot of critical global problems and need to developing an alternative approach to face economic and social development. This study aimed to review the spiritual-socio-cultural-economy values and criticize the application of Farm accounting cost. The concept reference of the study is based on Sufficiency Economy Philosophy paradigm combined with Laku Prihatin paradigm of Javanese culture, the main principles to create Sufficiency Economy Philosophy are Moderation, Reasonableness and Self Immunity. The study method used is critical ethnomethodology with a qualitative approach. The research site is in the Badegan area, Ponorogo Regency. The study results showed that 1) The concept of financing accounting in the Farm accounting does not represent the level of welfare of farmers, the welfare of farmers not oriented to material and (economic) growth but substance equitable dynamic values by a just relationship with God, society and the natural environment, 2) The concept of financing accounting should be in accordance with spiritual-socio-cultural values, by applying the cost of production with a Sufficiency Economy Philosophy and Net Farm Income (NFI) that is in favor of the farmers, 3) The principle of a Sufficiency Economy Philosophy provides good results for society in physical, social and economic aspects.
\end{abstract}

Keywords: Agricultural Accounting, cost of productions, net farm income, sufficiency economy philosophy

\section{Introduction}

The capitalist system coming from western countries and have developed in various countries in the world through the dominant ideology of liberalism. The capitalist system gives full freedom to economic actors to be able to play an active role for profit, so that it can lead to trade wars, political wars, technology wars, and biotechnology wars that lead to the Corona Virus Disease 19 Pandemic (COVID-19). The fall of the Ottoman Turkish Empire in 1924, the ideology of capitalism spreads to various countries where the majority of the people are Moslem in the world [1]. The ideology spreads to countries including Indonesia. This is evidenced by the development of accounting science in Indonesia based on the IFAC (International Federation of Accountants), so that the application in the field is always based on materialism (profit and loss). The agricultural industrial sector is regulated in International Accounting Standards (IAS) 41 and PSAK 69, thereby causing changes to the behavior of modern agriculture (from a culture which implies that agriculture is formed based on culture) to agribusiness. So that culture-based 
farmers are increasingly marginalized and replaced by multinational companies that are full of capital [2].

This study refers to previous research from Mulawarman [3], namely the cost of production which is reflected in the production input of net farm income is a very important operational part and is one of the determining factors for how much / how little profit is earned, the greater the production costs incurred the higher the cost of production that is formed. Soekartawi [4], which explains the calculation of farmer income, one of them is through Net Farm Income (NFI), NFI is used as a means of construction with other factors that can affect the calculation according to the reality in the field. Amir [5] and Kurniawan [2] through Net Farm Income (NFI / Agricultural Net Profit) and the concept of measurement and recognition of market-based biological assets in IAS 41 (Agriculture), which ideological substance is directly able to indoctrinate farmers into business paradigm agriculture. Farmers are no longer helpless because their roles have shifted to become government political commodities through regulations that have cornered the position of farmers [5]. According to reality, conventional accounting concepts do not represent agricultural accounting. The application of agricultural accounting in Indonesia, especially the Javanese, still mixes social and cultural aspects in practice. The pattern of thinking of the Javanese people is explained, said that natural resource management does not rely on material compliance only, it is necessary to pay attention to the limits where in the tradition of the Indonesian people can utilize and utilize nature, take what is appropriate, return excess, or replace what they have spent as compliance of consumption [6]. The cause of the welfare of agricultural sector workers is very concerning because the people's economy which is the national economic ideology based on article 33 of the 1945 Constitution is not implemented, ironically the capitalime system thrives in Indonesia.

Based on the description above, it is necessary to develop a new paradigm in accordance with the socio-cultural conditions of the community (especially Javanese farmer workers). A new paradigm is needed to improve the welfare of agricultural entrepreneurs both physically and mentally. The research theoretical framework used is the Sufficiency Economy Philosophy and the teachings of "Laku Prihatin" in Javanese society, Sufficiency Economy Philosophy (SEP) is a new paradigm in economics that is not too familiar yet in Indonesia. The history of Sufficiency Economy Philosophy comes from Thailand and was first initiated by the King Bhumibol Adulyajed and published in a state speech. The Definition of Sufficiency Economy Philosophy [7], [8], [9] said that SEP is a middle way that does not take sides with extreme thoughts, behavior and movements of the economic system. SEP has three main components which are used as principles in SEP, namely moderation, reasonableness, and Self Immunity [7], [8], [9], [10], [11]. This study criticizes the application of agricultural accounting costs and reconstructs the paradigm of accounting concepts in accordance with spiritual-socio-cultural values, by applying the cost of production with a Sufficiency Economy Philosophy and Net Farm Income (NFI) which sided with farmers. The importance of the principle of Sufficiency Economy Philosophy is needed so that Indonesia's human resources can quickly adapt to the times and can utilize existing natural resources more wisely. So that the researcher uses the philosophy of economics as a research paradigm.

\section{Method}

The research method used is critical ethnomethodology with a qualitative approach. The research design is not to collect data, but as an indication of the problems that occur by 
understanding individual behavior in a social environment to solving problems that occur. The problem portrayed is criticizing the application of conventional agricultural accounting costs and reconstructing the paradigm of accounting concepts according to spiritual-socio- cultural values to increase farmer welfare. The research site is in the Badegan area, Ponorogo Regency. The research location was chosen because the area is the one of the main agricultural material producer in Ponorogo Regency. Sources of data used in this study are primary data and secondary data. The Primary data taken directly by researchers and obtained from interviewees through interviews and documentation. Secondary data from books, research journals and published historical reports, as well as other documents related to research. The research structure in this study includes: Portrait of Sufficiency Economy Philosophy Application to Farmers, Agricultural Business Actor's Problems, Reconstruction of Production Cost with Sufficiency Economy Philosophy, and Reconstruction of the Application of Net Farm Income in favor of Farmers.

\section{Results and Discussion}

\subsection{Social, economic and cultural practices in the life of farmers}

The people of Ponorogo are majority Javanese, in carrying out the agricultural businesses, they always adhere to the teaching of religion and culture that they believe. They always behave in controlling their passions, patient, don't care about personal egos, honest in their actions, and sincere in responding a condition. The mindset and behavior affect their economic view. Besides getting profit, the purpose of farming is to balance the affairs of the world and the hereafter. So that capitalist economic practices are not implemented. Several findings in the field show that when it coming to harvest they will do the obligation of a relationship with God through zakat, it aims to increase gratitude and worship to Allah. Another expression of gratitude is by performing kenduri or better known as selamatan or kenduren (the designation of kenduri for Javanese people). They think that by holding a feast at every major harvest, they can give alms (sharing food) with relatives or neighbors, and also pray that the next harvest will be given a blessing to the bountiful harvest. This is one way to fulfill the inner needs of the farmer, the inner needs can be fulfilled if it is beneficial to others and more importantly how to please others first. Besides prioritizing religious teachings and human relations, farmers also prioritize the environment for sustainable agriculture. Inherited fields from their previous family are always maintained so they are not damaged, and not exploited in order to meet profit targets. This was evidenced by the farmers not fully using chemical fertilizers to keep the soil containing the best nutrients for plants and to increase the quality and quantity of the harvest. According to Dahana [6], which explains the management of natural resources that pays attention to the limits where Indonesian traditional people can explore and utilize nature, take what is needed, return excessive, or replace what they have consumed. The management of natural resources in the context of Sufficiency Economy Philosophy is intended for the common interest, meaning that all people make ends meet of natural resource management wisely because they have been limited by this sufficient value, there is no excessive exploitation of natural resources, and for sustainable interest means that the available natural resources can meet the needs of society at this time and society in the future. This is in accordance with Prawironegoro [12], explained that in the Islamic philosophy profit is the result of human work that is blessed by God for the 
welfare of human race, the preservation of the social environment, and the preservation of the natural environment.

The agricultural industry sector is regulated on its financial reporting standards specifically in International Accounting Standards (IAS) 41. IAS 41 is an accounting standard to regulate the agricultural industry sector contained in the global financial reporting standards of International Financial Reporting Standards (IFRS). In general, the scope of IAS 41 is to regulate the valuation of biological assets during their growth period until they reach the point of harvest. Biological assets are defined as living plants or animals available for agricultural production purposes. Meanwhile, land is recognized as fixed assets and investment assets, not as biological assets. So that the accounting treatment for land refers to IAS 40 and IAS 16. Biological assets are measured using fair value less estimated costs of sale from the initial recognition of biological assets to the point of harvest, unless fair value cannot be measured reliably at the time of recognition. Fair value at the time of initial measurement of biological assets cannot be valued reliably because prices are determined by the market. In this case, the entity is recommended to measure the biological assets cost less accumulated depreciation and any accumulated impairment losses. Once the fair value can be measured reliably, the biological assets must be valued at fair value less the estimated cost of sale. Changes in fair value less estimated selling costs are reported in the income statement for the period (actualization). When referring to conventional accounting, the costs incurred for operations must be charged into the calculation of the cost of goods manufactured. This regulation does not apply to Javanese farmers. Farmers will distinguish between costs that are private business with costs that are based on socio-cultural values, and are responsive to nature conservation. So that in terms of the concept of goods manufactured accounting cost financing, it is not suitable for application in the field if the calculation pattern of their cost of goods manufactured uses a cost accountingbased accrual approach. The accrual approach will reflect a high cost value because it requires the imposition of items that are considered as an element of sacrifice or expense. This concept is based on [2]. Farmers also have to charge costs that do not appear in real terms as costs in the farmer's calculations, such as depreciation expenses, interest expenses, costs, food expenses for operations, wages for family labor (not standard in determining wages), expenses for rituals (alms earth, feast of the big harvest), zakat, and payment of labor using the harvest.

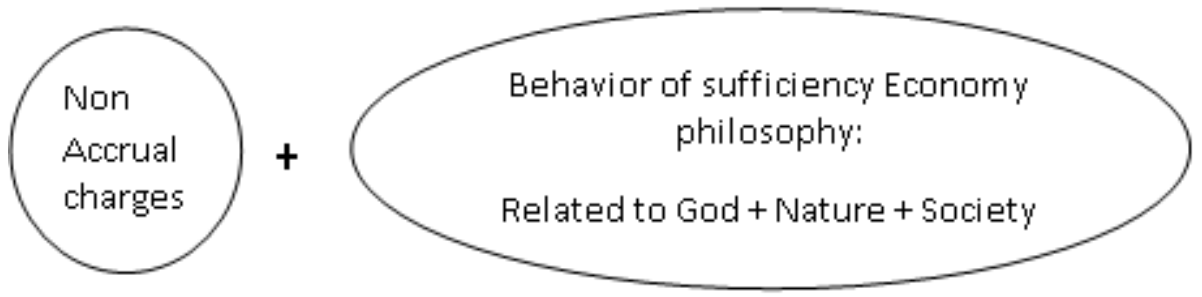

Fig. 1. The cost of productions according to the natural character of farmers as Javanese people

If the agricultural business calculates the cost of production on a broader basis (accrual), the farmer's income will be small. As a result, agricultural land is exploited to get a large profit as expected, and will damage the environment. The ultimate goal for the farmers is to increase their gratitude and worship to Allah when they get their sustenance, besides that their social relations with neighbors are also getting better and their relationship with nature is well maintained [5]. Indonesian farmers, especially Javanese, have a culture of Sufficiency Economy Philosophy, according [6] explaining that a Sufficiency Economy is an economic system that is 
based on noble values that are developed, maintained, and passed on by a culture. This noble value is the value of 'sufficient' itself, namely the value of being self-sufficient, limiting oneself to what is sufficient, not exaggerating or it can be termed not israf in Arabic which is interpreted as pointing to an attitude that exceeds the limits and is careless in doing something. These facts are in accordance with findings in the field, namely: moderation, guiding farmers' thoughts to be able to live their lives in the middle lane, not the extreme path. One should refrain from having too much fun. This way of life can be realized because of having wisdom (reasonableness) - the accumulation of knowledge and experience, along with analytical skills, self awareness, foresight, compassion and empathy. We all must be aware of the consequences of their actions, not only for themselves but for others as well. The third principle is SelfImmunity, which is the ability of farmers to protect themselves against various external challenges and adapt to various unpredictable and uncontrollable circumstances. Doing economic activities is not always oriented on materials, but must be balanced by paying attention to spiritual aspects, natural resources and social relations between communities. In terms of the character of farmers, they remain in a cultural mindset related to the calculation of the cost of farm production, so that their existence is maintained and protected from the capitalist system.

Government policy regulations and economic conditions are still not in favor of farmers, according to findings in the field there are several problems that occur, namely:

1. Farmers still rely on traditional knowledge, most of which are obtained by farmers from generation to generation so that technology and knowledge are rarely updated. When associated with conventional accounting, it is very ineffective and inefficient. Budget management literacy is very limited.

2. In terms of obtaining farmer's business capital. It is difficult to get the capital, because banks do not like the high risk of providing loans to farmers. Judging from the uncertain yields and the ability to pay is doubtful. This factor is quite difficult for farmers to develop or run their agricultural businesses.

3. Judging from the selling price of agricultural products based on market prices, of course there is interference from middlemen, owners of large capital and sophisticated technology. This is a practice of developing a capitalist economic system, with large- capital economic actors controlling the market, and farmers being made workers whose welfare is not given much attention. Farmers do not have a big role in determining the selling price of their crops, so farmers always depend on the selling price and the amount of profit from their harvest is always uncertain.

4. In terms of the availability of fertilizers and pesticides to anticipate disease and plant pests, the sales are dominated by production and marketing by private companies, especially multinational companies. This means that the standard setting for the selling price of agricultural inputs is also dominated by companies, so that the mark bcompanies whose prices are so fluctuating.

In accordance with these problems, in order to form net farm income on the side of farmers as an effort to create independent agriculture, the main thing that must be paid attention is the selling price of agricultural commodities. As well as stabilizing prices and supplies of chemical fertilizers and pesticides. The selling price and stability of pesticide fertilizers are the most influencing factors for farmers' income. Some of these problems require government intervention to regulate the selling price and stability of fertilizers. Especially through regional regulations, the government must also be able to fix the marketing pattern so that there is no more distribution mafia playing in it. 


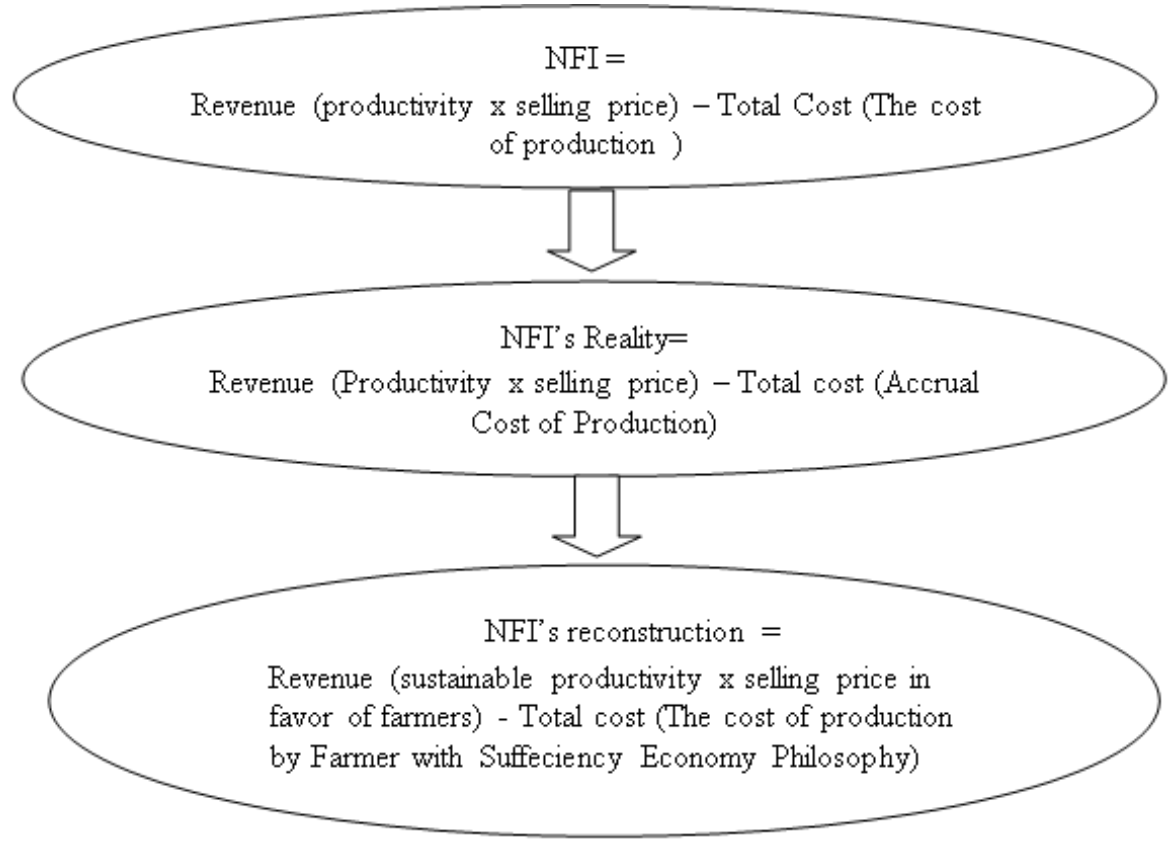

Fig. 2. The concept of net farm income in accordance with the character of farmers as Javanese people

Farming is a subsistence job, also knows and applies the concept of net income. However, there is a difference between the concept of net income based on accounting standards and the net farm income applied by farmers. Farmers apply net farm income through spiritual-sociocultural values. In carrying out his work, he is limited not to become greedy people who destroy nature. When they have to reduce costs, farmers will prioritize aspects of local wisdom such as taking turns to become rewang at harvest time, not always being paid with money but paying with the harvest. This smart initiative based on traditional knowledge is an act of self-protection from the impact of the spread of the capitalist system. So the welfare of farmers is not oriented towards material and (economic) growth but has the substance of dynamic values that are just related to God, society and the natural environment. The mindset of farmers emphasizes the matter of "being well off", farmers will feel enough with a low profit, rather than having to make a big profit, but their natural agricultural and social conditions must be at stake.

\subsection{The Urgency of the Application of SEP for Sustainable Development}

Sufficiency Economy Philosophy (SEP) acts as one of the unique indicators in achieving sustainable (environmental, economic and social) and cultural development. 


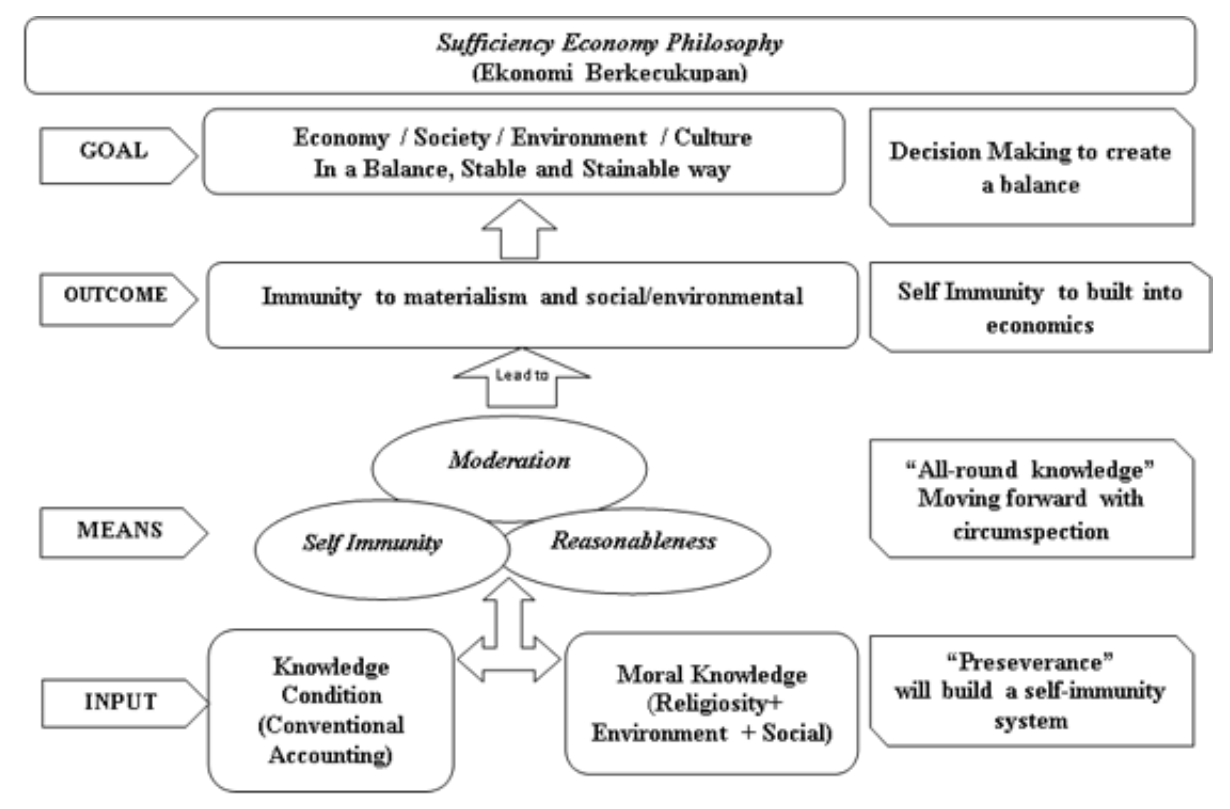

Fig. 3. Illustration of the relationship and the role of each component in an economy sufficient to achieve sustainable development

From the research, it is found that the importance of emphasizing the application of the principle of Sufficiency Economy gives good results for society in physical, social and economic aspects. In the social and economic aspects, the principles of using sufficient resources, participating in community development and sufficient consumption lead to better social economic aspects. First, concern for the environment and moderate consumption have an impact on household economic stability. Families that change their lifestyle based on the principle of Sufficiency Economy are able to reduce unnecessary items, and are able to provide economic stability in the household. Second, it shows that families that apply Sufficiency Economy principles have a better time to discuss and plan for household financial management and provide better health and better relationships between families.

Third, the principle of a Sufficiency Economy can increase the level of happiness of the community, seen from their perception of satisfaction, family health and better family relationships.

\section{Conclusion}

The concept of conventional accounting is not suitable for agricultural business actors to apply to Javanese people, especially Ponorogo, because the financial accounting concept in agricultural accounting does not represent the level of farmers 'welfare, farmers' welfare is not material-oriented and economic growth, but has a substance dynamic value related to God, society and the natural environment. So that the concept of financing accounting should be in accordance with spiritual-socio-cultural values, by applying the cost of production with a Sufficiency Economy Philosophy and Net Farm Income (NFI) which is in favor of farmers, the 
principles that are the main pillars of creating a Sufficiency Economy Philosophy, namely Moderation, Reasonableness, and Self Immunity. The principle of an adequate economy provides good results for society in physical, social and economic aspects.

\section{References}

[1] Gambling, T., dan R.A.A. Karim, Business and Accounting Ethics in Islam. London - New York: Mansell Publishing Limited, 1991.

[2] Kurniawan, R., Mulawarman, A. D., \& Kamayanti, A. "Biological Assets Valuation Reconstruction: A Critical Study of IAS 41 on Agricultural Accounting in Indonesian Farmers", Procedia - Social and Behavioral Sciences, no. 164, pp. 68-75, August. 2014.

[3] Mulawarman, A. D.’Tazkiyah: Metodologi Rekonstruksi Akuntansi Pertanian’. Assets. Jurnal akuntansi dan pendidikan Unipma, Vol 8, No 2. 2019.

[4] Soekartawi, et. al., Ilmu Usaha Tani dan Penelitian Untuk Pengembangan Petani Kecil. Jakarta: Penerbit Universitas Indonesia, 1986.

[5] Amir, et al., 2014. Gugurnya Petani Rakyat: Perang Laba Pertanian Nasional. Malang: UB Press, 2014.

[6] Dahana, R.P, Ekonomi Cukup: Kritik Budaya pada Kapitalisme. Jakarta: Penerbit Buku Kompas. 2015.

[7] U-tantada, S, et al., "Sufficiency economy and sustainability," In The 2nd Multidisciplinary Research and Innovation for Globally Sustainable Development (MRIGSD), pp. 84-94, extra issue. 2016.

[8] Mongsawad, P. "The Philosophy of the Sufficiency Economy: A Contribution to the Theory", AsiaPacific Development Journal, vol. 17, no. 1, pp. 123-143. 2010.

[9] Wibulwasdi, C., Piboolsravut, P., \& Pootrakol, K, "Sufficiency Economy Philosophy and Development", 2016, Available: http://www.sufficiencyeconomy.org.

[10] Thailand. Ministry of Foreign Affairs, K. Sufficiency Economy Philosophy: Thailand's Path towards Sustainable Development Goals Second Edition (A publicat, Vol. Second Edi). Kingdom of Thailand, Ministry of Foreign Affairs. 2017.

[11] Mongsawad, P., and Thongpakde, N, "Sufficiency Economy Philosophy: A Holistic Approach to Economic Development and Mainstream Economic Thought”, Asian Social Science, vol. 12, no. 7, pp. 136-142. 2016.

[12] Prawironegoro, D, "Filsafat Akuntansi: Laba Berdasar Pandangan Kapitalisme, Marxisme dan Spiritualisme Islam.” Disertasi, Pascasarjana Fakultas Ekonomi dan Bisnis Universitas Brawijaya, Malang, Indonesia, 2014. 